\title{
Analisis Prior Knowledge Konsep Asam Basa Siswa Kelas XI SMA untuk Merancang Modul Kimia Berbasis REACT
}

\author{
Fauzana Gazali ${ }^{1)}$ Eka Yusmaita ${ }^{2)}$ \\ 1)) Staf Pengajar Jurusan Kimia, FMIPA Universitas Negeri Padang \\ ${ }^{2)}$ Staf Pengajar Jurusan Kimia, FMIPA Universitas Negeri Padang \\ fauzanagazali10@gmail.com
}

\begin{abstract}
This study is a define phase of 4D model used in Research and Development (R\&D) that aims to explore initial concept of grade XI students on acid-base topic before studying the material. Instrument used in this study was a two-tiered diagnostic test in the form of multiple-choice questions with choice of reasons that consisted of 16 items. The test was given to 100 grade XI students from various schools in West Sumatra. Students' answers were processed by grouping them into 3 categories: understand, have misconceptions and do not understand. Data were then analyzed descriptively by calculating the percentage of students' learning difficulties in all of competency achievement indicators that had been compiled. The results showed that students had difficulty in understanding some concepts of acid base such as acid base theory of Arrhenius (75.2\%), of Bronsted-Lowry (81.43\%), and of Lewis (100\%); pH (94.04\%); and acid base ionization constant $(97.33 \%)$. Results of this research are then used as a consideration in the development of acid-base module designed for grade XI Senior High School learning.
\end{abstract}

Keywords :prior knowledge, acid base,two tier diagnostic test

(i) This is an open access article distributed under the Creative Commons 4.0 Attribution License, which permits unrestricted use, distribution, and reproduction in any medium, provided the original work is properly cited. $\odot 2018$ by author and Universitas Negeri Padang.

\section{PENDAHULUAN}

Teori belajar konstruktivisme menuntut agar peserta didik mampu memiliki kontribusi aktif dari dalam dirinya terhadap proses belajar dengan membangun pengetahuannya sendiri dengan cara mengkombinasikan antara informasi baru dan pengalaman dengan struktur pengetahuan yang sudah ada (Zainal A, 2015). Senada dengan hal itu, pembelajaran bermakna menurut Ausubel merupakan suatu proses mengaitkan informasi baru pada konsep-konsep relevan yang terdapat dalam struktur kognitif seseorang (Slameto, 2010). Pembelajaran yang berorientasi pada pengetahuan awal akan memberikan dampak pada proses dan perolehan belajar yang memadai. Sesuai dengan pandangan konstruktivistik, pembelajaran bermakna akan terwujud jika peserta didik sudah mampu menghubungkan fenomena baru yang dipelajari kedalam struktur pengetahuan mereka. Artinya, konsep baru yang dipelajari siswa harus sesuai dengan keterampilan siswa dan dikaitkan dengan konsep-konsep yang sudah mereka miliki sebelumnya. Dalam proses belajar bermakna ini, seseorang dapat mengembangkan pengetahuan yang sudah ada, atau dapat mengubahnya sesuai dengan informasi baru yang mereka peroleh. Dengan demikian peserta didik mengkonstruksi apa yang ia pelajari sendiri berdasarkan pengetahuan awal (prior knowledge) mereka.

Berdasarkan pengetahuan dan pengalam an awal siswa, maka pada saat pemaknaan konsep berlangsung, informasi yang diterima berubah secara perlahan dari konteks umum ke dalam konteks khusus bidang ilmu, kemudian dihubungkan dengan beragam aktivitas atau kejadian yang akan memacu untuk terus mencari dan menemukan. Kemampuan siswa yang dicapai melalui proses pembelajaran, pemaham an, dan kebermaknaan dapat diwujudkan oleh siswa dalam berbagai bentuk perolehan belajar (Brahmantara, 2013).

Prior knowledge merupakan kombinasi antara pengetahuan dan keterampilan yang dibangun oleh siswa sebelum melalui proses pembelajaran yang akan mempengaruhi informasi baru untuk ditambahkan kestruktur pengetahuan yang sudah ada (Hailikari, 2009). Menciptakan kesempatan yang menantang kepada para peserta didik dengan cara memanggil kembali prior knowledge merupakan upaya yang penting dilakukan agar pendidik 
dapat mengubah pola fikir dari mengingat informasi yang pernah dimiliki peserta didik menjadi proses belajar yang penuh makna.

Dalam proses belajar, prior knowledge merupakan kerangka dimana peserta didik menyaring informasi baru dan mencari makna tentang apa yang sedang dipelajari olehnya. Proses membentuk makna melalui membaca di dasarkan pada prior knowledge akan mencapai tujuan pembelajaran yang diinginkan sehingga dapat dikatakan bahwa prior knowledge merupakan elemen esensial yang menciptakan proses belajar menjadi sesuatu yang bermakna (Razi, 2012).

Jonassen dan Gabrowski dalam Muisman (2003) menyatakan pengetahuan awal merupakan pengetahuan, keterampilan, atau kemampuan yang dibawa peserta didik ke dalam proses belajar, sedangkan pengetahuan awal itu sendiri merupakan suatu bentukan yang terus menerus oleh peserta didik setiap saat mengalami reorganisasi karena adanya pengalaman-pengalaman baru.

Pengetahuan awal siswa yang tidak memadai atau terfragmentasi merupakan masalah penting yang harus dipertimbangkan karena jika ada ketidaksesuaian antara harapan guru terkait pengetahuan siswa dan pengetahuan dasar siswa yang sebenarnya, maka proses pembelajaran akan terhambat sejak awal (Hailikari, 2008). Mempelajari sesuatu tanpa memiliki pengetahuan awal yang cukup, kurang, atau bahkan mengalami miskonsepsi terhadap suatu konsep dapat mengakibatkan pembelajaran dengan menghafal konsep tanpa memaknainya. Pembelajaran seperti ini dapat terjadi jika siswa tidak dapat menghubungkan pengetahuan baru dan pengetahuan awal yang telah ada dalam kerangka berfikir mereka. Dengan demikian jelas tergambar bahwa pengetahuan awal sangat penting dalam rangka mengkonstruk pengetahuan siswa.

Secara garis besar, setiap peserta didik memiliki kemampuan yang berbeda-beda sehingga kecepatannya dalam menyelesaikan tujuan pembelajaran pun berbeda juga. Oleh sebab itu selain pembelajaran di sekolah, siswa juga memerlukan bahan ajar yang membantu mereka memahami konsep-konsep untuk mencapai tujuan pembelajaran sesuai kecepatan masing-masing. Namun ketersediaan bahan ajar yang sesuai dengan teori kontruktivisme masih terbatas. Oleh karena itu, perlu dirancang bahan ajar berupa modul materi asam basa yang dikembangkan berdasarkan pertimbangan sejauh mana prior knowledge siswa tentang teori asam basa ini.

Gerlach dan Ely dalam Harjanto (2006) menyatakan "prior knowledge dapat ditentukan dengan memberikan tes awal". Penilaian prior knowledge siswa pada awal pembelajaran merupakan suatu tindakan penting untuk dukungan instruksional (Hailikari, 2008). Dengan mengetahui prior knowledge siswa, memungkinkan guru untuk mengidentifikasi konsep penting apa saja yang diperlukan siswa terkait pembelajaran yang akan dilakukan sehingga, guru dapat memberikan materi ajar yang tepat, tidak terlalu mudah, dan tidak terlalu sukar bagi siswa. Namun, penilaian prior knowledge siswa saja tidak cukup, siswa juga harus diberikan umpan balik tentang kinerja mereka dan guru mesti menyadari bagaimana hasil penilaian tersebut dapat digunakan dalam desain instruksional.

Salah satu cara untuk mengetahui prior knowledge siswa mengenai suatu konsep adalah dengan memberikan tes (pilihan ganda dan uraian) dan non tes (wawancara, observasi, dan angket) terkait materi yang akan dipelajari. Dalam pembelajaran sains, tes pilihan ganda sering digunakan dibandingkan wawancara dan angket. Namun, dalam tes pilihan ganda guru tidak dapat menjamin siswa benar-benar paham dengan konsep yang ditanyakan atau hanya menjawab soal dengan menebak. Untuk meminimalisir hal ini, maka soal tes yang diberikan dapat berupa tes diagnostik bertingkat dua, dimana tingkat pertama menyatakan pilihan jawaban dan tingkat kedua menyatakan alasan siswa memilih jawaban tersebut.

Hasil penilaian prior knowledge siswa ini selanjutnya dianalisis dan berguna bagi guru untuk mempersiapkan bahan ajar yang diperlukan oleh siswa, sehingga materi kimia SMA yang tadinya padat dengan teori cukup menampilkan cuplikan materi esensial yang dibutuhkan siswa. Salah satu bahan ajar yang dapat digunakan dalam pembelajaran kimia di SMA adalah modul. Namun ketersediaan modul yang sesuai dengan teori belajar konstruktivistik di lapangan masih belum ada. Oleh karena itu, deskripsi prior knowledge siswa yang diperoleh dari penilaian hasil tes diagnostik bertingkat dua ini dijadikan dasar awal pengembangan konten/isi dari modul yang dibuat. Konsep materi yang bermasalah dan sulit bagi siswa dijadikan penekanan materi /konten dari modul 
yang dibuat. Dengan demikian, bahan ajar berupa modul dibuat sesuai dengan pengetahuan awal siswa dan mendukung teori belajar kontruktivisme.

\section{METODE PENELITIAN}

Penelitian ini merupakan tahap awal dari penelitian dan pengembangan (R\&D). Tahapan pertama pada penelitian ini bertujuan untuk menganalisis prior knowledge siswa tentang konsep asam basa sebagai bahan pertimbangan dalam pengembangan bahan ajar berupa modul asam basa model REACT (Relating, Experiencing, Applying dan Transfering) untuk siswa kelas XI SMA.

Adapun instrumen pengumpul data yang digunakan adalah tes diagnostik bertingkat dua yang disertai dengan pilihan alasan. Menurut Arikunto (2009: 34) tes diagnostik merupakan tes yang digunakan untuk mengetahui kelemahankelemahan siswa sehingga berdasarkan kelemahan-kelemahan tersebut dapat diberikan perlakuan yang tepat. Tes diagnostik adalah alat atau instrumen yang digunakan untuk mengidentifikasi kesulitan belajar (Suwarto, 2012: 113). Menurut depdiknas (2007), tes diagnostik memiliki dua fungsi yaitu untuk mengidentifikasi masalah atau kesulitan yang dialami siswa dalam belajar dan untuk merencanakan tindak lanjut berupa upaya-upaya pemecahan masalah sesuai dengan kesulitan yang telah terindentifikasi. Dalam penelitian ini, tes diagnostik two tier yang diberikan berfungsi untuk merencanakan tindak lanjut berupa pemecahan masalah yang ditemukan melalui perancangan content/ isi bahan ajar berupa modul yang sesuai dengan prior knowledge siswa.

Adapun tujuan penggunaan tes diagnostik ini adalah untuk menentukan pengajaran yang perlu dilakukan di masa mendatang baik berupa penggunaan metode mengajar yang tepat, bahan ajar yang diperlukan, maupun pemanfaatan media yang sesuai dengan materi pokok dan karakteristik siswa. Dengan mempertimbangkan prior knowledge siswa peneliti berharap dapat merancang bahan ajar berupa modul yang berisi materi ajar yang diperlukan siswa untuk pembelajaran kimia SMA.

Data penelitian ini, dikumpulkan dengan menggunakan soal tes diagnostik two-tier yang sudah standar dan sudah diuji validitas dan reliabilitasnya. Soal yang diberikan terdiri dari 16 butir soal dengan kriteria validitas cukup dan reliabilitas tinggi dimana koofisien korelasi masing-masing adalah sebesar 0,471 dan 0,769 (Rositasari, 2014). Adapun beberapa contoh butir soal tes diagnotik yang diberikan adalah seperti yang ditampilkan pada Gambar 1.

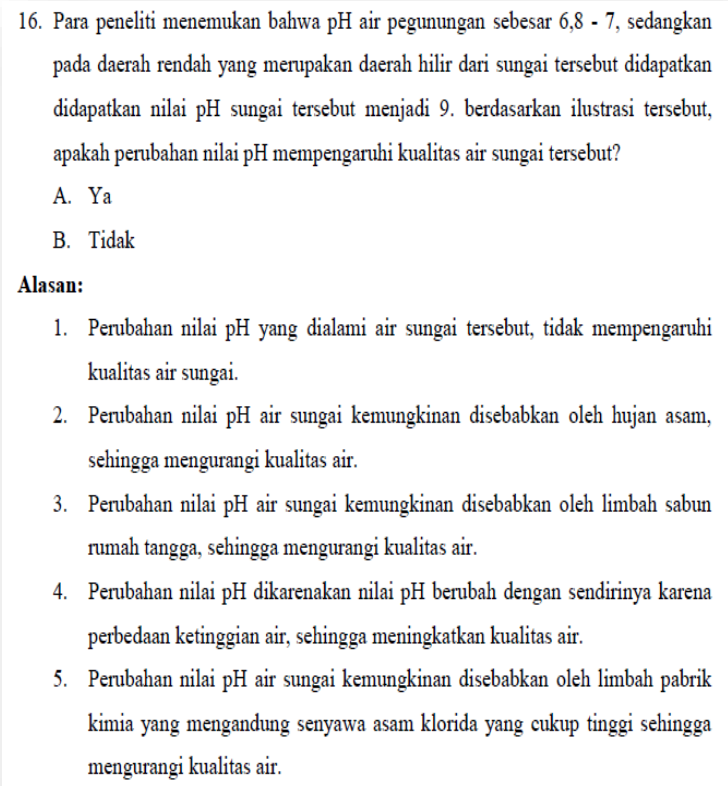

1. Perubahan nilai $\mathrm{pH}$ yang dialami air sungai tersebut, tidak mempengaruhi kualitas air sungai.

2. Perubahan nilai $\mathrm{pH}$ air sungai kemungkinan disebabkan oleh hujan asam, sehingga mengurangi kualitas air.

3. Perubahan nilai $\mathrm{pH}$ air sungai kemungkinan disebabkan oleh limbah sabun rumah tangga, sehingga mengurangi kualitas air.

4. Perubahan nilai $\mathrm{pH}$ dikarenakan nilai $\mathrm{pH}$ berubah dengan sendirinya karena perbedaan ketinggian air, sehingga meningkatkan kualitas air.

5. Perubahan nilai $\mathrm{pH}$ air sungai kemungkinan disebabkan oleh limbah pabrik kimia yang mengandung senyawa asam klorida yang cukup tinggi sehingga mengurangi kualitas air.

Gambar 1. Contoh butir soal tes diagnostik

Siswa yang mampu menjawab soal pada gambar 1 dengan benar dan memberikan alasan yang benar pada tingkat 2, berarti mereka mengetahui bahwa senyawa asam dan basa masuk ke sungai dapat mempengaruhi $\mathrm{pH}$ air sungai. Sehingga jika air sungai tercampur dengan senyawa yang bersifat asam maka nilai pH akan berkurang. Sebaliknya jika senyawa yang tercampur kedalam air sungai adalah basa, maka $\mathrm{pH}$ air sungai akan meningkat. Dari sebagian besar alasan jawaban yang diberikan siswa pada soal Gambar 1, dapat diketahui bahwa siswa masih belum mampu menentukan sumbersumber polutan yang bersifat asam dan basa yang berasal dari lingkungan.

Tes diagnostik bertingkat dua seperti Gambar 1 diberikan kepada 100 orang siswa yang berasal dari 3 sekolah berbeda di Sumatera Barat. Sekolah yang dijadikan sebagai subjek penelitian adalah SMAN 1 Padang Panjang, SMAN 2 Payakumbuh, dan SMAN 5 Sijunjung. Sekolahsekolah tersebut dianggap sudah mewakili masing-masing tingkatan SMA di Sumatera Barat yang dipilih berdasarkan informasi perengkingan dari dinas terkait.

Adapun kelebihan tes diagnostik two-tier menurut Tuysuz ( 2009) adalah pada tingkat 1 
terjadi penurunan kesalahan pengukuran. Dalam pertanyaan objektif satu tingkat dengan 5 option jawaban, terdapat kemungkinan $20 \%$ siswa menjawab soal tersebut dengan menebak jawaban yang benar. Pertanyaan dengan dua tingkat dianggap benar hanya jika siswa berhasil menjawab soal dan memberikan alasan dengan benar. Dengan demikian seseorang siswa yang menjawab sebuah pertanyaan dengan 5 option jawaban ditingkat 1 dan 5 option jawaban ditingkat 2 hanya memiliki $4 \%$ kemungkinan tebakan yang benar secara acak.

Prior Knowledge siswa tentang konsep asam basa dapat diketahui dari jawaban siswa pada 16 butir soal tes diagnostik diberikan. Pada metode ini, setiap item soal terdiri dari dua tingkat soal, yaitu pilihan jawaban soal dan pilihan alasan. Bagian pertama dari setiap item pilihan ganda merupakan suatu pertanyaan dengan lima pilihan jawaban. Bagian kedua terdiri dari beberapa pilihan jawaban yang menjadi alasan pemilihan jawaban pada bagian pertama. Untuk mengidentifikasi kesulitan siswa dalam memahami konsep, maka jawaban yang diberikan oleh siswa tersebut dikategorikan seperti pada tabel 1 berikut.

Tabel 1. Kemungkinan Pola Jawaban Siswa dan Kategorinya

\begin{tabular}{ll}
\hline Pola Jawaban Siswa & $\begin{array}{l}\text { KategoriTingkat } \\
\text { Pemahaman }\end{array}$ \\
\hline Jawaban inti tes benar-alasan benar & Memahami \\
Jawaban inti tes benar-alasan salah & Miskonsepsi \\
Jawaban inti tes salah-alasan benar & Miskonsepsi \\
Jawaban inti tes salah-alasan salah & Tidak memahami \\
Jawaban inti tes salah-alasan tidak & Tidak memahami \\
diisi & \\
Tidak menjawab inti tes dan alasan & Tidak memahami \\
\hline (Sumber: Salirawati,2010) &
\end{tabular}

Untuk mengetahui kemampuan pemahaman siswa dianalisis dengan menggunakan rumus

$$
\begin{aligned}
& P=\frac{\text { jumlah siswa benar }}{\text { jumlah siswa keseluruhan }} \times 100 \% \\
& \% \mathrm{~K}=100 \%-\mathrm{P} \text {........(2) }
\end{aligned}
$$

Keterangan:

$\mathrm{P}=$ Persentase siswa yang tidak mengalami kesulitan belajar tiap indikator soal
$\% \mathrm{~K}=$ Persentase siswa yang mengalami kesulitan belajar (miskonsepsi + tidak paham) tiap indikator soal (Sriningsih, 2015:3).

\section{HASIL DAN PEMBAHASAN}

\section{Hasil Penelitian}

Berdasarkan hasil tes diagnostik two-tier yang diberikan, maka tingkat pemahaman siswa terhadap konsep asam basa dikategorikan menjadi tiga bagian, yaitu siswa yang memahami (P), mengalami miskonsepsi (M) dan tidak memahami (TP). Data yang diperoleh ditampilkan dalam Tabel 2.

Tabel 2. Data Hasil Tes Diagnostik Tiap Indikator Pembelajaran

\begin{tabular}{crrrrc}
\hline \multirow{5}{*}{ Indikator } & \multicolumn{1}{l}{ So } & & & & \\
& \multicolumn{1}{l}{ Soal } & $\% \mathrm{P}$ & $\% \mathrm{M}$ & $\% \mathrm{TP}$ & $\mathrm{M}+\mathrm{TP}$ \\
\hline \multirow{2}{*}{1} & 1 & 29.2 & 35.7 & 35.0 & 70.7 \\
& 3 & 28.6 & 27.7 & 43.7 & 71.4 \\
& 7 & 16.7 & 58.2 & 25.1 & 83.3 \\
\hline \multirow{2}{*}{2} & 2 & 12.5 & 20.0 & 67.5 & 87.5 \\
& 5 & 10.8 & 35.5 & 53.7 & 89.2 \\
& 6 & 18.6 & 30.0 & 51.4 & 81.4 \\
\hline 3 & 4 & 0.0 & 32.4 & 67.6 & 100.0 \\
\hline 4 & 16 & 32.7 & 54.7 & 12.6 & 67.3 \\
\hline \multirow{2}{*}{5} & 11 & 27.8 & 39.9 & 32.3 & 72.2 \\
& 9 & 15.2 & 33.0 & 51.7 & 84.8 \\
\hline 6 & 8 & 100.0 & & & 0.0 \\
\hline \multirow{2}{*}{7} & 10 & 8.9 & 32.6 & 58.5 & 91.1 \\
& 12 & 5.1 & 24.3 & 70.5 & 94.9 \\
& 13 & 3.9 & 24.0 & 72.1 & 96.1 \\
\hline \multirow{2}{*}{8} & 14 & 2.8 & 29.3 & 68.0 & 97.2 \\
& 15 & 2.6 & 24.9 & 72.5 & 97.4 \\
\hline
\end{tabular}

Data pada tabel 2 menunjukkan bahwa persentase siswa yang memahami konsep, mengalami miskonsepsi dan tidak paham pada masing-masing item soal berbeda-beda. Persentase siswa yang memahami konsep tertinggi adalah pada soal no 8 yaitu sebesar $100 \%$ dan terendah yaitu soal no 4 sebesar $0 \%$ artinya semua peserta tes teridentifikasi tidak paham dengan konsep yang ditanyakan pada soal 
nomor 4. Sedangkan persentase siswa yang mengalami miskonsepsi tertinggi terdapat pada soal nomor 7 yaitu sebesar 58,2\% dan persentase miskonsepsi terendah terdapat pada soal 8 yaitu sebesar 0\%. Miskonsepsi dapat terjadi ketika siswa mengkonstruksi pemahamannya sendiri terhadap suatu konsep dan tidak ada jaminan bahwa mereka sudah mengkonstruksi pemahaman yang akurat. Akibatnya konsepsi siswa yang terbentuk tidak sesuai dengan pengertian ilmiah dan konsepsi para ilmuan (Suparno, 2013).

Untuk persentase siswa yang tidak paham konsep (TP) tertinggi terdapat pada soal nomor 15 yaitu senilai $72,5 \%$ dan persentase terendah adalah pada soal nomor 8 yaitu senilai $0 \%$. Dari semua data pada tabel 2 dapat disimpulkan bahwa sebagian besar siswa mengalami kesulitan dalam memahami hampir semua konsep pada tiap indikator. Siswa yang mengalami kesulitan memahami konsep terlihat dari jumlah persentase siswa yang tidak paham (TP) dan siswa yang mengalami miskonsepsi (M) dalam menjawab soal tersebut. Konsep yang sulit bagi siswa adalah soal yang jumlah $\% \mathrm{M}+\% \mathrm{TP}$ nya menunjukan nilai $75 \%$ keatas.

Berdasarkan pengolahan data hasil tes diagnostik siswa seperti yang terlihat dalam Tabel 2, dapat diketahui bahwa konsep yang sulit bagi siswa antara lain soal terkait teori asam basa arrhenius (indikator 1), bronsted lowry (indikator 2), dan lewis (indikator 3), kekuatan asam basa (indikator 5) ,menghitung $\mathrm{pH}$ larutan (indikator 7) serta derajat ionisasi asam dan basa (indikator 8). Untuk lebih jelasnya, informasi ini digambarkan dalam grafik batang pada Gambar 2.

\section{Persentase Kesulitan Siswa Memahami Tiap Indikator}

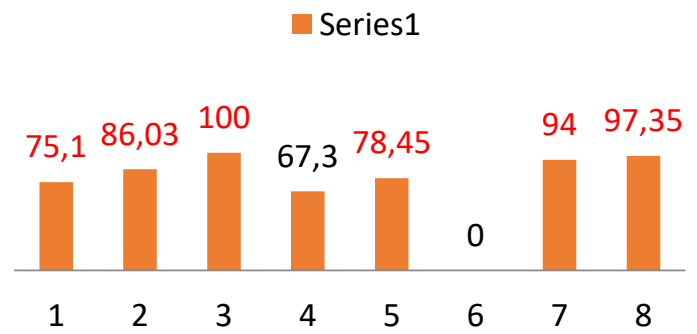

Gambar 2 Persentase Kesulitan Siswa Memahami Tiap Indikator

\section{Pembahasan.}

Pengetahuan awal siswa diperoleh saat mereka berada pada tingkat pendidikan yang lebih rendah (SD/SMP), berdasarkan kejadiankejadian yang mereka alami, serta melalui pengamatannya saat berinteraksi dengan masyarakat dalam kehidupan sehari-hari. Konsep awal siswa yang kurang tepat karena tidak sesuai dengan konsep ilmiah dapat pula bertahan lama dan sulit diubah/diperbaiki pada tingkat pendidikan formal. Dari penelitian yang telah dilakukan, diberikan tes diagnostik bertingkat dua (two-tier) untuk mengetahui persentase miskonsepsi siswa dari segi pemahaman konsep. Tes diagnostik adalah tes yang digunakan untuk mengetahui secara tepat dan memastikan kelemahan dan kekuatan siswa pada pelajaran tertentu. Tes diagnostik yang digunakan pada penelitian ini yaitu tes diagnostik dengan instrumen pilihan ganda yang disertai pilihan alasan. Tes diagnostik ini terdiri dari 16 item soal yang mewakili 8 indikator pencapaian kompetensi.

\section{a. Indikator 1}

Indikator 1 terkait dengan konsep asam basa arrhenius. Soal yang mengukur indikator 1 ini adalah soal nomor 1, 3, dan 7. Persentase kesulitan siswa dalam menjawab soal terkait indikator 1 ini adalah sekitar 75,1\%. Dari 100 siswa peserta tes, $40,5 \%$ siswa mengalami miskonsepsi dan 34,6\% siswa tidak paham dengan konsep asam basa arrhenius. Hal ini disebababkan karena ditingkat pendidikan sebelumnya mereka memang belum pernah belajar tentang teori asam basa. Jadi pengetahuan awal atau prior knowledge siswa tentang teori asam basa masih sangat kurang.

\section{b. Indikator 2}

Indikator 2 yaitu menjelaskan asam basa menurut Bronsted-Lowry. Soal yang terkait dengan indikator 2 ini adalah soal nomor 2, 5, dan 6. Berdasarkan data yang diperoleh, sebagian besar siswa mengalami kesulitan dalam menjawab soal-soal tersebut. Data menunjukkan bahwa hanya $14 \%$ siswa yang mampu menjawab soal-soal itu dengan benar, sisanya sekitar $86,03 \%$ siswa mengalami miskonsepsi. Tingginya nilai persentase siswa yang mengalami miskonsepsi pada indikator 2 ini disebabkan karena sebagian besar siswa belum mampu membedakan konsep asam basa 
Arrhenius dan konsep asam basa Bronsted Lowry. Selain materi ini tergolong baru bagi siswa kelas XI SMA, pengetahuan awal mereka juga belum memadai atau dapat dikatakan belum ada terkait konsep ini. Dengan demikian, pemahaman konsep asam basa menurut ahli ini harus lebih ditekankan dalam pembelajaran yang dilakukan atau dijabarkan dalam bahan ajar sedemikian rupa.

\section{c. Indikator 3}

Indikator 3 ini yaitu menjelaskan asam basa menurut Lewis. Soal terkait indikator 3 ini hanya ada 1 soal yaitu soal nomor 4 . Konsep asam basa arhenius ini terindikasi paling sulit bagi siswa. Hal ini disebabkan karena tidak ada peserta tes yang dapat menjawab soal ini dengan benar. Sebagian besar siswa yaitu sekitar $67,6 \%$ tidak paham dalam menyelesaikan soal ini, sisanya $32,4 \%$ peserta tes mengalami miskonsepsi. Jadi secara keseluruhan, soal ini tergolong sulit bagi siswa dengan persentase kesulitannya adalah 100\%. Miskonsepsi dan ketidakpahaman siswa mengenai teori asam basa lewis juga dijumpai dalam penelitian Suyono 2010 dan meylindra dkk (2013) dimana persentase miskonsepsi yang teridentifikasi lebih dari 50\%. Hal ini berarti bahwa sebagian besar siswa masih mengalami kesulitan dalam memahami teori asam basa lewis.

\section{d. Indikator 4 dan 6}

Indikator 4 adalah menjelaskan pengaruh pengionan asam basa terhadap kesetimbangan air dan indikator 6 yaitu menghitung tetapan kesetimbangan asam basa. Konsep kesetimbangan air dan tetapan kesetimbangan merupakan dua konsep yang tingkat kesulitannya paling kecil bagi siswa yaitu 67,3\%. Artinya diantara konsep yang lain, banyak siswa yang mampu menjawab soal terkait konsep ini dengan benar. Dari jawaban yang diberikan siswa, terlihat mereka mampu mengaplikasikan konsep kesetimbangan air pada peristiwa dalam kehidupan sehari-hari. Mereka mengetahui bahwa dengan berubahnya $\mathrm{pH}$ air sungai akan berpengaruh pada kualitas air sungai tersebut. Sebagian besar siswa mampu menghubungkan alasan kenapa $\mathrm{pH}$ air dihulu sungai berbeda dengan $\mathrm{pH}$ air di muara sungai. Mereka dapat menjawab bahwa limbah sabun rumah tangga merupakan salah satu penyebab $\mathrm{pH}$ air sungai di muara lebih basa dibanding $\mathrm{pH}$ air sungai di hulu.

\section{e. Indikator 5}

Indikator 5 yaitu menjelaskan kekuatan asam basa. Soal yang diberikan terkait indikator ini adalah soal no 11 dan 9. Pada soa tersebutl, siswa diminta membandingkan kekuatan asam asetat $0,1 \mathrm{M}$ dengan asam klorida $0,1 \mathrm{M}$. Dari 100 orang peserta tes, hanya $21,5 \%$ peserta yang mampu menjawab soal tersebut dengan memberikan alasan yang berhubungan dengan kemampuan larutan terionisasi dalam air mempengaruhi kekuatan asam. Sementara $78,45 \%$ peserta tes lainnya mengalami kesulitan menjawab soal tersebut dengan teridentifikasi $36,45 \%$ siswa yang mengalami miskonsepsi dan $42 \%$ siswa yang tidak paham sama sekali tentang konsep kekuatan asam basa.

\section{f. Indikator 7 dan 8}

Indikator 7 dan 8 adalah indikator yang tingkat kesulitannya sangat tinggi bagi siswa. Berdasarkan hasil analisis tes diagnostik yang diberikan diketahui tingkat kesulitan masingmasing indikator ini adalah $94 \%$ dan $97,35 \%$. Hal ini menunjukkan prior knowledge siswa tentang menghitung $\mathrm{pH}$ dan derajat ionisasi asam basa masih sangat kurang atau dapat dikatakan belum ada. Dari jawaban yang diberikan siswa tergambar bahwa mereka belum mengetahui apa itu $\mathrm{pH}$ larutan dan bagaimana cara menghitungnya. Sebagian besar siswa tidak memahami bahwa dalam larutan asam selalu mengandung ion $\mathrm{H}^{+}$dan dalam larutan basa selalu mengandung ion $\mathrm{OH}^{-}$dengan konsentrasi tertentu. Apabila konsentrasi ion $\mathrm{H}^{+}$dan ion $\mathrm{OH}^{-}$ dikalikan maka akan diperoleh angka $10^{-14}$. Begitu juga yang terjadi pada soal-soal yang berhubungan dengan konsep derajat ionisasi asam basa pada indikator 8. Karena belum mengerti tentang $\mathrm{pH}$, mereka juga tidak bisa menghitung derajat ionisasi asam basa, sebab soal-soal yang diberikan berhubungannya juga dengan konsep $\mathrm{pH}$. Jawaban yang diberikan siswa kebanyakan merupakan hasil tebakan semata, hal ini terlihat dari pilihan jawaban dan pilihan alasan yang diberikan tidak berhubungan sama sekali.

\section{KESIMPULAN}

Berdasarkan analisis hasil tes diagnostik bertingkat dua yang telah dilakukan maka dapat disimpulkan bahwa, sebagian besar siswa SMA yang menjadi subjek penelitian mengalami 
kesulitan dalam memahami beberapa konsep asam basa seperti teori asam basa arrhenius dengan persentase kesulitan belajar siswa yaitu $75,2 \%$, konsep asam basa bronsted lowry dengan persentase kesulitan $81,43 \%$ dan konsep asam basa lewis dengan persentase kesulitan $100 \%$. Konsep lainnya yang terindikasi sulit bagi siswa adalah konsep yang menyangkut perhitungan derajat keasaman $(\mathrm{pH})$ dan derajat ionisasi asam basa dengan persentase kesulitan siswa memahami masing-masing konsep ini yaitu 94,04\%, dan 97,33\%. Selain itu, miskonsepsi paling banyak ditemukan dalam menjawab soalsoal yang berkaitan dengan contoh asam basa menurut lewis, indikator asam basa, serta menghitung $\mathrm{pH}$ larutan. Konsep yang sulit bagi siswa ini selanjutnya harus dijadikan penekanan dalam bahan ajar berupa modul yang sedang dirancang.

\section{UCAPAN TERIMAKASIH}

Pada kesempatan ini, penulis mengucapkan terima kasih kepada Lembaga Penelitian dan Pengabdian Masyarakat (LP2M) Universitas Negeri Padang yang telah mendanai penelitian ini melalui Dana DIPA Universitas Negeri Padang Tahun Anggaran 2018 Nomor: SP-DIPA 042.01.2.400929/2018 tanggal 5 Desember 2017. Penulis juga mengucapan terimakasih kepada Kepala sekolah dan majelis guru SMAN 1 Padang Panjang, SMAN 2 Payakumbuh, dan SMAN 5 Sijunjung yang telah mengizinkan kami mengumpulkan data di sekolah yang bersangkutan, serta semua pihak yang telah membantu dalam penyelesaian penelitian dan penyusunan artikel ini.

\section{DAFTAR PUSTAKA}

Arifin, Zainal. (2015). Analisis dan Perancangan Modul Representasi Knowledge Building dalam Student Centered e-Learning Environment. Jurnal online. Tersedia: https://www.researchgate.net/publication/2 66584515

Arikunto, S. (2009). Dasar- Dasar Evaluasi Pendidikan. Jakarta: Rineka Cipta Algensido.

Brahmantara, dkk. (2013). Pengembangan Multimedia Pembelajaran Berbasis Pengetahuan Awal Untuk Mata Pelajaran Fotografi Bagi Siswa Kelas X Smk Ti Bali Global Singaraja. e-Journal Program
Pascasarjana Universitas Pendidikan Ganesha, Volume 3 Tahun 2013

Hailikari, T. (2009). Assessing university students' prior knowledge: Implications for theory and practice. Finland: Helsinki University

Hailikari, T. (2008). The Relevance of Prior Knowledge in Learning and Instructional Design. American Journal of Pharmaceutical Education 2008; 72 (5) Article 113

Muisman. 2003. Analisis jalur hasil belajar mata pelajaran berdasarkan kecerdasan, strategi metakognitif, dan pengetahuan awal. Tesis. PPs IKIP Negeri Singaraja

Razi, P, dkk. 2012. Analisis Pengetahuan awal mahasiswa tahun pertama jurusan fisika FMIPA UNP. Laporan penelitian DIPA UNP.

Rositasari, D, dkk. 2014. Pengembangan Tes Diagnostik Two-Tier untuk Mendeteksi Miskonsepsi Siswa SMA pada Topik Asam Basa. Journal Edusains Vol 6 no 2 hal. 169176

Salirawati, Das. (2010). Pengembangan Model Instrumen Pendeteksi Miskonsepsi Kimia pada Peserta Didik SMA. Yogyakarta : PPs Universitas Negeri Yogyakarta

Slameto. (2010). Belajar dan faktor-faktor yang mempengaruhinya. Jakarta : Rineka Cipta.

Sriningsih. (2015). Analisis Kesalahan Konsep Mahasiswa pada Pokok Bahasan Reaksi Oksidasi Reduksi. Jurnal Penelitian. Universitas Negeri Gorontalo

Suwarto. (2013). Pengembangan Tes Diagnostik dalam Pembelajaran. Yogyakarta: Pustaka Pelajar.

Tuysus, C. (2009). Development of Two-Tier Instrument And Asses Student Understanding in Chemistry. Scientific Research and Essay, 4(6): 623-628.

Undang-Undang Republik Indonesia No.20 Tahun 2003. Sistem Pendidikan Nasional. Jakarta: Departemen Pendidikan Nasional. 